Japan. J. Med. Sci. Biol., 32, 327-336, 1979

\title{
ULTRASTRUCTURAL STUDY OF MYCOBACTERIA IN EXPERIMENTALLY PRODUCED LUNG LESIONS OF MICE*
}

\author{
Koomi KANAI, Eiko KONDO** and Tomoyoshi YASUDA*** \\ The First Department of Bacteriology, **Department of Tuberculosis, \\ and ***Laboratory of Technology, National Institute of Health, \\ Shinagawa-ku, Tokyo 141
}

(Received, September 26, 1979. Accepted, October 25, 1979)

\begin{abstract}
SUMMARY: Mice were infected by iv injection with a virulent strain of Mycobacterium bovis, Ravenel strain, to prepare specimens for electron microscopical observation of their intracellular morphology. Observation was made with ultrathin sections of the granulomatous lungs at an advanced stage of infection. Many apparently intact bacterial cells were found intracellularly, and the majority of them had lipoidal inclusions enclosed by a membranous structure. Several layers of mycobacterial cell wall were discernible, including a fairly wide space of the electrontransparent zone just beneath the electrondense outmost layer. Mesosomes, nuclear material, small dense granules and cross wall were found in almost the same appearance as those reported of mycobacteria grown in vitro. The bacilli were located mainly within intact or damaged phagosomes which were often filled with amorphous material of various electron densities.
\end{abstract}

\section{INTRODUCTION}

Brieger and Glauert (1954) demonstrated for the first time a ultra-thin electron microscopical picture of tubercle bacilli in the mouse lung lesion. This was possible only at an advanced stage of infection with a heavy inoculum. Otherwise, they could not find any bacilli by usual methods. They found transverse and longitudinal sections of intracellular bacilli, but little information was derived therefrom about the internal structure.

Merckx, Brown and Karlson (1964) also demonstrated an electron microscopical picture of virulent mycobacteria in the mouse lung lesions. They observed the bacilliary forms in an electron-transparent zone enclosed by a thin outlining membrane in histiocytes. In addition, they found numerous large, lamellated, osmophilic bodies ( $\mathrm{X}$ bodies) in necrotic lesions, which he interpreted as the result of interaction between lysosomes and tubercle bacilli.

* This study was supported bv a rrant (No. 467077) from the Ministry of Education, Science and Culture, and also by a special project grant from the Ministry of Health and Welfare.

金井興美（国立予防衛生研究所 細菌第一部）

近藤瑩子（" 結核部）

保田友義（＂技術部） 
However, the fine structure of the bacilli themselves was not revealed in any detail.

On the other hand, the ultrastructural morphology of mycobacteria grown in culture medium or in tissue culture cells has become increasingly clear with the technical progress in electron microscopy (Toda et al., 1957; Shinohara, Fukushi and Suzuki, 1957; Toda et al., 1960; Fukushi et al., 1960; Armstrong and Hart, 1971).

Under such a situation, our interest in the pathogenesis of tuberculous infection at a cellular level led us to our own electron microscopical study on the fine structure of tubercle bacilli growing in vivo. The results are in good agreement with the recent observations by Leake, Ockers and Myrvik (1977) of M. bovis (Ravenel) in tissue-cultured cells.

\section{MATERIALS and Methods}

The materials and methods employed in this study were the same as those described in the preceding paper (Kanai, Kondo and Yasuda, 1979a).

\section{Results}

The infection produced with $0.5 \mathrm{mg}$ of $M$. bovis (Ravenel) was so severe that most of the mice reached moribund states in 3 to 4 weeks. It is known that such an inoculum can multiply during this period to the level of $10^{10}$ viable counts per lung (Kondo et al., 1971). The lung became heavily granulomatous. Specimens were prepared from the lungs of 3-week infection.

Figure 1 was chosen as an example of the ultrastructure of lesion containing many morphologically intact bacilli. The central part of this plane of section may be a damaged polymorphonuclear leukocyte and the cells located in the upper right and the lower left appear to be macrophages. The phagosomes with or without bacillary forms are not always intact.

Figures 2A-B show the longitudinal sections of intracellular mycobacterial cells. In Fig. 2A, a cross wall is seen indicating that the bacterial cell was in cell division, and it is still in a phagosome though its limiting membrane is ruptured. In Fig. 2B, the bacterial cell (lower left), which appears to be located completely free in the cytoplasm of the host cell, show two lipoidal inclusions enclosed by a well-defined membranous structure. The nuclear material is recognized as a low-density area with fibrous material. The outmost layer of the cell wall can be seen as an electrondense tenuous line. An electron-transparent zone is present just beneath the outmost layer. Two or three more layers are also discernible in some sites. In the bacterial cytoplasm, many small electrondense granules are scattered.

Figures 3A-E show various features of the bacilli in polymorphonuclear leukocytes. Lipoidal inclusions are clear in most of them. As shown in Figs. 


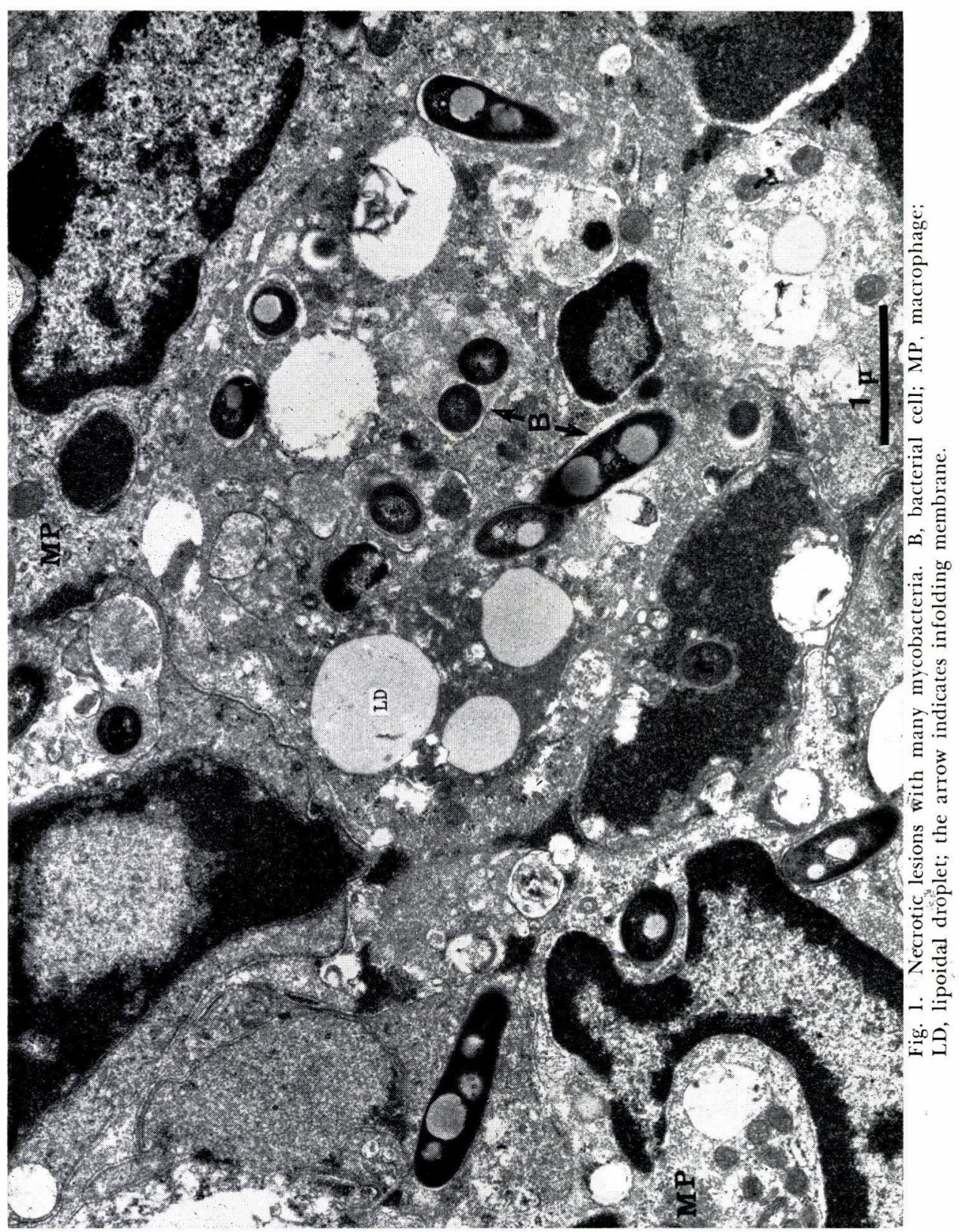



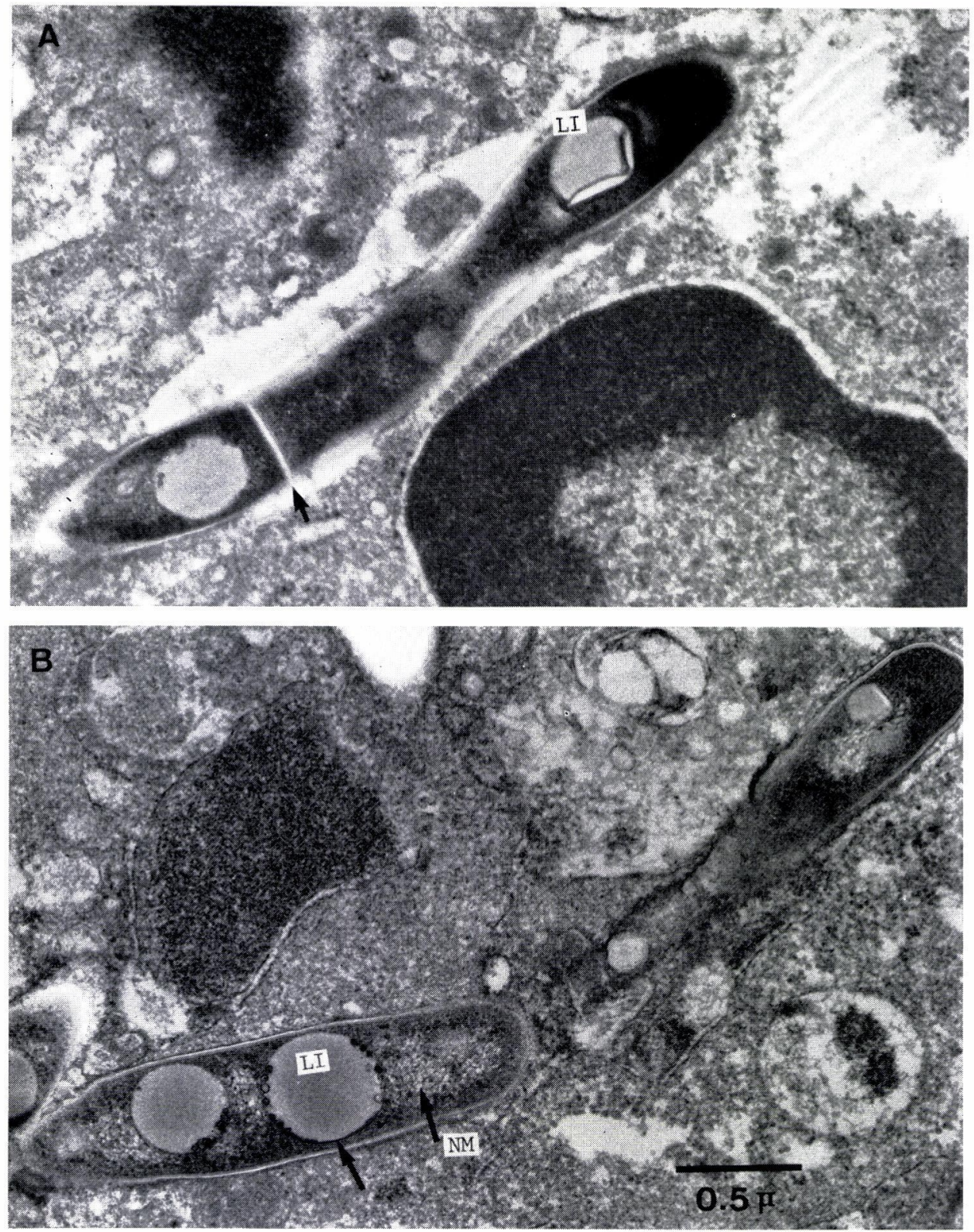

Fig. 2. Longitudinal sections of intracellular mycobacteria. A. A mycobacterial cell is located within what appears to be a ruptured vacuole. LI, lipoidal inclusion; the arrow indicates cross wall. Magnification is the same as B. B. Two mycobacterial cells are located free in the cytoplasm of the host cell. NM, nuclear material; LI, lipoidal inclusion; the arrow indicates membranous structure limiting lipoidal inclusion. 
$3 \mathrm{~A}$ and $\mathrm{C}$, most bacilli are surrounded by amorphous material of various electron-densities and encircled incompletely by what appears to be remnants of the phagosomal membrane. One of the bacilli in Fig. $3 \mathrm{~B}$ shows a mesosomal structure. In another bacterial cell in the same figure, various layers of the cell are clearly seen. The bacterium shown in Fig. 3D is located within a typical tight phagosome, in which the phagosomal membrane is very close to the outmost layer of the cell wall of the ingested mycobacterium and there is no apparent electron-transparent zone between them. A small vesicle is fusing with the phagosomal membrane. In the right side of this phagosome, we see a cytosegresome indicating autophagic event. In Fig. 3E, we see four crosssectioned mycobacteria located in the peripheral cytoplasm of a leukocyte which probably adheres to the capillary wall.

Figures 4A-D demonstrate various features of cross-sectioned mycobacteria in macrophages. In Fig. 4A, a mycobacterial cell located within a phagocytic vacuole shows a highly electron-dense round granule of about $25 \mathrm{~nm}$ in diameter. In the upper right corner, there is a large dense body which appears to be an autophagic vacuole. In Fig. 4C, there are two bacilli each within a separate phagocytic vacuole. The lower right one appears to be in close contact with the limiting membrane of phagosome on one side, thus leaving a spacious electron-transparent zone on the other side. In the upper center of this picture, there is a large dense vacuole of pear-form. This vacuole appears to be in fusion with the bacillus-containing vacuole on the left side. Figures $4 \mathrm{~B}$ and $\mathrm{D}$ show bacillary forms probably in a degenerating stage within phagosomes. The left one in Fig. $4 \mathrm{~B}$ appears to have lost its intact cell was structure, and the cytoplasm is granular and swelling. This form is associated with the membranous layers which appear to be developing from the limiting membrane of the phagosome. In contrast, the bacillary form in the right phagosome with electron-light material looks intact. In Fig. 4D, the mycobacterial cell in the upper phagosome may be in the initial stage of degeneration. The electron-density of bacterial cytoplasm decreases and the cell wall is discontinuous in its layered organization. This phagosome is also permeated with electron-light material. These two light-staining or electron-transparent phagosomes are surrounded by electrondense material.

\section{Discussion}

The present study succeeded in demonstrating the fine structure of virulent mycobacteria staying in mouse lung lesions. In view of such experiences of Brieger and Glauert (1954) that detection of infecting mycobacteria in ultrathin tissue sections was possible only in the specimens at an advanced stage of infection, we produced severe infection in the mouse lungs by iv injection of a fairly large virulent inoculum. The organisms of Ravenel strain keep on multiplication of the logarithmic phase until deaths of the animals and viable counts can reach the level of $10^{10}$ bacteria per lung (Kondo et al., 1971). Under 

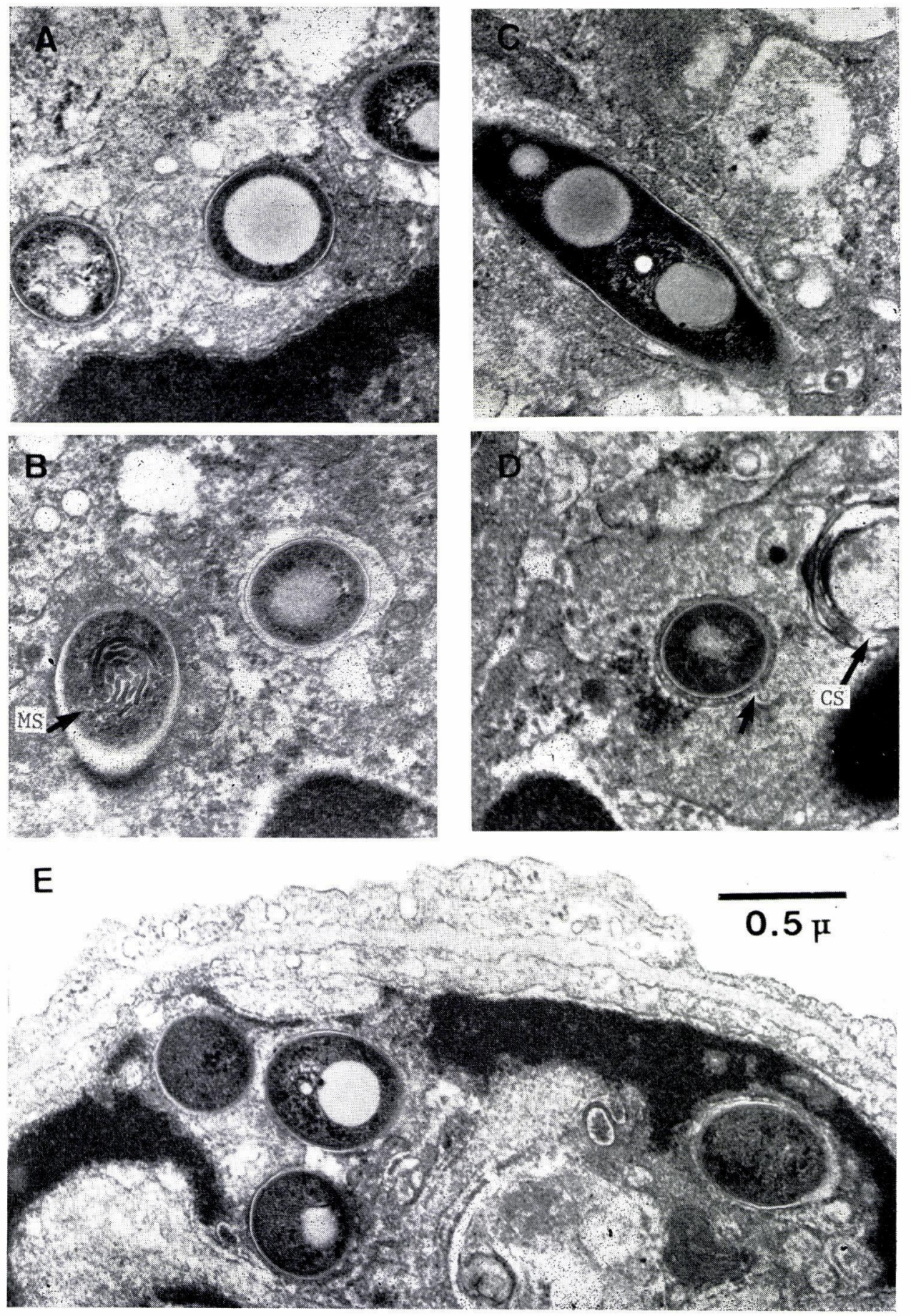


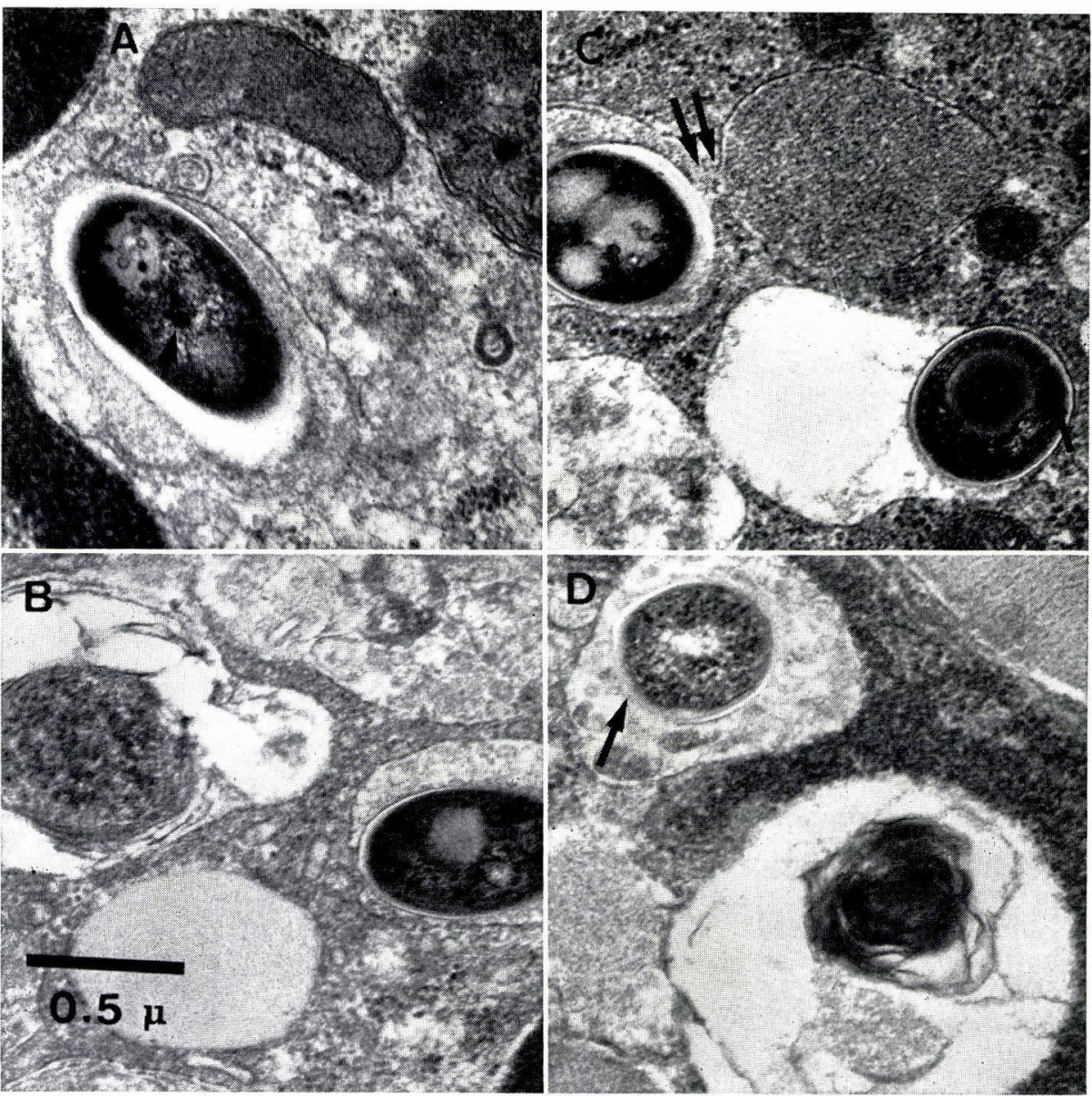

Fig. 4A-D. Various forms of mycobacteria within macrophages. The arrows in $\mathrm{A}$ and $\mathrm{C}$ indicate highly electron-dense granules. Double arrows in $\mathrm{C}$ indicate fusion of a pear-form dense body with the adjacent phagocytic vacuole with a mycobacterial cell. The arrow in D indicates discontinuity in intact cell wall layers.

this experimental condition, it was easy to detect the morphologically intact bacilli in thin sections.

The ultrastructural morphology of the intracellular bacilli was basically the same as those reported by other authors on mycobacteria grown in vitro. Only one notable difference was the presence of electron-light round bodies in the bacilli grown in vivo. They were often surrounded by what appeared to be a limiting membrane. This structure may be the same as the low dense body

Fig. 3A-E. Various forms of mycobacteria within polymorphonuclear leukocytes. MS in B, mesosome; CS in D, cytosegresome; the arrow indicates fusion of a small vesicle with the limiting membrane of bacterium-containing tight phagosome. Magnification of A to D is equal to $\mathrm{E}$. (see p. 332) 
found by Toda et al. (1960) in H37Rv tubercle bacilli ingested by tissue-cultured HeLa cells. They did not find such a body in the same strain of tubercle bacilli grown in vitro. Fukushi et al. (1960) also observed a similar body in tubercle bacilli grown in tissue-cultured mononuclear cells.

More recently, the presence of such bodies was confirmed by Leake, Ockers and Myrvik (1977) in M. bovis (Ravenel and BCG) staying within tissuecultured rabbit peritoneal macrophages, and also by Barksdale and Kim (1977) in mycobacteria grown in mouse footpads. They were called by them lipidfilled vacuoles, plate-like formation or lipoidal inclusions.

As for the cell wall, careful observation recognized at least four layers; the electron-dense outmost layer, the fairly wide electron-transparent zone, the electron-dense layer, and the less electron-dense layer in the order from the outside to the inside. The chemical nature of these layers be explained from the models presented by Imaeda, Kanetsuna and Galindo (1968) and Barksdale and Kim (1977).

The cytoplasmic membrane was sometimes seen as a tenuous line. In the cytoplasm, there were many small dense granules. Mesosomes of vesiculated type were also present. The presence of mesosomes in mycobacteria grown in vivo was demonstrated for the first time in $M$. lepraemurium by Chapman, Hanks and Wallace (1959). Nuclear materials were seen as fibrous material in an electron-light area. Occasionally, probable polyphosphate granules were detected as the most dense granule of around $25 \mathrm{~nm}$ in diameter. All these structures were not different from those reported by previous authors in mycobacteria grown in vitro.

As stated before, the majority of mycobacterial cells in thin-sections appeared morphologically intact. This observation may be related with the fact that, in this mode of infection, the bacilli in the lung tissue are in the logarithmic phase of growth at the time of specimen harvest. We should be also aware of a pathological feature that, because of thus increasing amount of infecting bacilli, the exudative reaction continued with a large number of polymorphonuclear leukocytes. In fact, the polymorphonuclear leukocytes, though most of them being destroyed, were predominant in the fields of thin-sections, and mononuclear cells were fewer.

As presented in the preceding paper (Kanai, Kondo and Yasuda, 1979a), polymorphonuclear leukocytes in the normal mouse lungs have many electrondense round lysosomal granules. In the infected mouse lungs, however, polymorphonuclear leukocytes with mycobacteria did not have such well-defined lysosomal granules. Probably, they were consumed by the process of fusion with phagocytic vacuoles to release hydrolytic enzymes therein. It is quite likely that the phagolysosomes thus produced would have subsequently been ruptured to release ingested mycobacteria free into the cytoplasm and simultaneously to let the enzymes leak into there. These events may result in vacuolation and degeneration of the cytoplasm as we saw in the fields of thin-sections

Unlike polymorphonuclear leukocytes, macrophages generally retained a 
rather normal condition even when they were infected. They showed various intracellular organelles; mitochondria, lysosomes, endoplasmic reticulum associated with or without ribosomes, Golgi complex, autographic vacuoles, and lipoidal droplets. Mycobacteria-containing phagosomes were often permeated with low density material as Dumont and Sheldon (1964) indicated in tuberculous granuloma experimentally produced in the peritoneal cavity of the hamster. Some other times, such vacuoles were surrounded by lysosomes containing electrondense material. However, no definite view would be derived from the present observations regarding the mechanism by which macrophages handle ingested mycobacteria. Such aspects should be studied in mice in which the protective mechanisms are overwhelming against infecting mycobacteria, particularly with specimens of the epithelioid cell system as employed by Nishi (1978).

\section{Acknowledgements}

Appreciation is expressed to Prof. K. Fukushi, Department of Microbiology, Hirosaki University Medical School, for his kind advice for this study.

\section{REFERENCES}

Armstrong, J. A. AND Hart, P. D. (1971): Response of cultured macrophages to Mycobacterium tuberculosis, with observations on fusion of lysosomes with phagosomes. J. Exptl. Med., 134, 713-740.

BARKSDAle, L. AND KIM, K. S. (1977): Mycobacterium. Bacteriol. Rev., 41, 217-372.

Brieger, E. M. and Glauert, A. M. (1954): The demonstration of tubercle bacilli in ultrathin sections of infected tissues by electron microscopy. Tubercle, 35, 80-85.

Chapman, G. B., Hanks, J. H. and Wallace, J. H. (1959): An electron microscopic study of the disposition and fine structure of Mycobacterium lepraemurium in mouse spleen. J. Bacteriol., 77, 205-211.

Dumont, A. And Sheldon, H. (1965): Changes in the fine structure of macrophages in experimentally produced tuberculous granuloma in hamsters. Lab. Invest., 14, 2035-2055.

Fukushi, K., Yamaguchi, J., Hasuike, T., Suzuki, T., Utagawa, K. and Sato, T. (1960): Electron microscopic studies of tubercle bacilli-Fine structure of tubercle bacilli in mononuclear cells and HeLa cells. Proc. 16th Sci. Meeting, Soc. Electron-Microscop., Japan. B-21, 52-54.

ImaEdA, T., Kanetsuna, F. AND Galindo, B. (1968): Ultrastructure of cell walls of genus Mycobacterium. J. Ultrastruct. Res., 25, 46-63.

KANAI, K., Kondo, E. AND YAsUdA, T. (1979a): Ultrastructural changes in the alveolar epithelium in response to mycobacterial infection, with special reference to lamellar inclusions. Japan. J. Med. Sci. Biol., 32, 315-325.

Kondo, E., Murohashi, T., Kanai, K. And Kubota, S. (1971): Esterification of tissue cholesterol with fatty acids in the lungs of tuberculous mice. Japan. J. Med. Sci. Biol., 24, 345-356.

LeAKe, E. S., Ockers, J. R. AND MYrvik, Q. N. (1977): In vitro interaction of the BCG and Revenel strain of Mycobacterium bovis with rabbit macrophages: Adherence of the phagosomal membrane to the bacterial cell wall and the problem of the peribacillary space. J. Reticuloendothel. Soc., 22, 129-147.

Merckx, J. J., Brown, A. L. JR. And Karlson, A. G. (1964): An electron microscopic study of experimental infections with acid-fast bacilli. Am. Rev. Resp. Dis., 89, 485-496.

Nishi, K. (1978): Possible role of lysosomes in cells of "the epithelioid cell system". Acta Histochim. Cytochim., 11, 252-268.

Shinohara, C., Fukushi, K. ANd Suzuki, J. (1957): Mitochondria-like structures in ultrathin sections of Mycobacterium avium. J. Bacteriol., 74, 413-415. 
Toda, T., KoIke, M., Hiraki, N. And TAKeyA, K. (1957): The intracellular structures of a mycobacterium. J. Bacteriol., 73, 442-443.

Toda, T., Takeya, K., Kolke, M. AND MoRI, R. (1960): Electron microscopy of ultra thin sections of Mycobacterium. I. Fine structures of the cells grown in vitro and in vivo. Proc. Japan Acad., 36, 372-375. 